

\title{
KANT, RESPECT, AND HYPOTHETICAL ACTS
}

\author{
JOHN SHAND
}

\begin{abstract}
The role of hypothetical acts, as opposed to actual acts, has been neglected in understanding the nature of what is required by the Respect for Persons formulation of the Categorical Imperative in concrete moral relations between persons. This had led to a failure to understand fully the way and the extent to which the Categorical Imperative may be present in all such relations with others as encapsulated in an appropriate attitude towards others that may refer to hypothetical acts, as well as actual acts. The result is an underestimation of the direct relevance and moral efficacy of the Categorical Imperative.
\end{abstract}

\section{1.}

It has sometimes been claimed that Kant's Categorical Imperative is 'empty' in that from it one may not derive any specific duties or forbid any maxims as impermissible. ${ }^{1}$ This thought may be applied to both formulations of the Categorical Imperative if one accepts that they are logically equivalent. ${ }^{2}$ The focus here is on the second formulation of the Categorical Imperative as Respect for the Dignity of Persons. ${ }^{3}$ Kant's Categorical Imperative, understood through the Formula of the End-in-Itself or Respect for the Dignity of Persons reads, 'Handle so, daß du die Menschheit sowohl in deiner Person, als in der Person eines jeden andern jederzeit zugleich als Zweck, niemals bloß als Mittel brauchst. ${ }^{4}$ ['Act so that you treat humanity, whether in your own person or in the person of any other, always as an end and never merely as a means'. ${ }^{5}$ ] When referring to the Categorical Imperative here, it is this second formulation based on respect that is meant (henceforth simply the 'Categorical Imperative').

The claim that the Categorical Imperative is merely formal needs to be separated from another claim, namely that at best only a few very general actual positive and negative duties may be derived from the Categorical Imperative. This may lead to the further contention that, although the Categorical Imperative is not empty, its application in practice in particular concrete situations is highly limited and vague at best (morally 'thin', may be another way of putting this) or virtually non-existent at worse. In short, it may be said that it is hard to see what work the Categorical Imperative is doing morally in governing the relations between people. When no actual acts that are supposedly derived from the Categorical Imperative are involved in the relations between people, it

\footnotetext{
${ }^{1}$ This claim originally derives from Hegel. Henry E. Allison, Idealism and Freedom: Essays on Kant's Theoretical and Practical Philosophy (Cambridge: Cambridge University Press, 1996), 143

${ }^{2}$ No claim is made here to their logical equivalence, rather it is a matter of pointing out what would follow if true. The fact of it or not is irrelevant to the argument presented here concerning the 'respect' formulation of the Categorical Imperative.

${ }^{3}$ Also sometimes referred to as The Formula of Humanity as End in Itself. cf. Allen W. Wood, Kant's Ethical Thought (Cambridge: Cambridge University Press, 1999), 18.

${ }^{4}$ Foundation of the Metaphysics of Morals, Chapter II, AA 4:429. 9-12. Kant in fact refers to it as 'Der praktische Imperativ' AA 4:429.9 (The practical imperative...).

${ }^{5}$ I have slightly modified the rendition of this from the Paton translation consulted, by changing 'simply' to 'merely'. Immanuel Kant, Groundwork of the Metaphysic, Trans H. J. Paton (London: Harper \& Row. 1964).
} 
may be questioned whether the Categorical Imperative is involved in the relation at all. This is however is a mistake, and results from the exclusive tendency to see the principle of the Categorical Imperative as existing in relations between people only if there are actual acts indicting or displaying its presence.

This, however, is to completely ignore the role of hypothetical acts that would indicate that the Categorical Imperative is in play. ${ }^{6}$ There may be no or few actual acts involved in the relations between persons that show that the principle is in play, and this might lead one to conclude that the principle is absent in the relation between persons. However, this overlooks that even when little or nothing by way of actual acts indicates that the Categorical Imperative principle is in play, there may be many morally relevant hypothetical acts present in the relations between persons that exist latently, captured by our always having the appropriate attitude towards others. These acts, although generally unarticulated, partly because the circumstances that might give rise to them are inherently unpredictable and indeterminate, consist of things one would or would not do, should such and such a circumstance arise.

It may be objected that the reason for not considering hypothetical acts is that they are not acts and so can have no place in determining whether the Categorical Imperative is in play in the relations between people. This is to overlook the way in which hypothetical acts may be embodied or encapsulated in the attitude of one person to another even when no actual acts are present. The appropriate attitude according to the Categorical Imperative is one of respect. Having the right attitude to another is indeed the essence of the Categorical Imperative. ${ }^{7}$ That the right attitude of respect is present, even when no actual acts are displaying it, may be shown because of the range of hypothetical acts that would follow from the attitude should certain circumstances arise. The connection here might be displayed as follows.

\footnotetext{
${ }^{6}$ It might be thought that the importance of the notion of hypothetical acts in relation to the second formulation of the Categorical Imperative, insofar as it exists as it should in the relations between people, has been abundantly explored by others writing on Kantian ethics. This appears not to be the case at all as indicated by a sample of some of the most prominent writers. Onora O'Neill, Constructions of Reason: Explorations of Kant's practical philosophy (Cambridge: Cambridge University Press, 1989), is, among others, representative of this. O’Neill says 'Agency must be not merely (negatively) respected but (positively) fostered...' op cit, 140. While there is talk here of positive and negative duties or maxims, there is no talk of hypothetical duties and the acts they imply. Similarly, Allen W. Wood, Kant's Ethical Thought (Cambridge: Cambridge University Press, 1999), 139-141, and 147-150, talks of positively having to sympathise with others, and negatively a duty not to commit suicide, but there is no reference to hypothetical acts, let alone to the vast array of them that may more or less probably become actual. There is merely mention of actual positive (helping) acts and negative (not hindering) acts, and that more than the latter is a duty in our relations to others. But this is not the same as hypothetical acts, nor can they be reduced to actual positive and negative acts. Similarly with Christine M. Korsgaard, The Sources of Normativity (Cambridge: Cambridge University Press, 1996). The closest one gets is Roger J. Sullivan, Immanuel Kant's Moral Theory (Cambridge: Cambridge University Press, 1989) who on 70 identifies, I believe correctly, 'respect as an attitude (and the conduct displaying that attitude)'. However, he fails to make the connection between respect, attitude and hypothetical acts, rather than merely a connection to actual conduct that may or may not be taking place in any given relation between people. This leaves us with the puzzle: when there is no conduct displaying the attitude, has the appropriate attitude ceased to exist? Surely not necessarily; indeed often in fact not at all. The appropriate attitude, that of respect, prevails because of the way it is embodied in hypothetical acts that would display it.

${ }^{7}$ Roger J. Sullivan, Ibid, 70.
} 
Categorical Imperative $\rightarrow$ respect $\rightarrow$ attitude $\rightarrow$ actual acts + hypothetical acts

What is often missed in the analysis of the role played by the Categorical Imperative in relations between people is hypothetical acts. Indeed the relationship between the Categorical Imperative and hypothetical acts, as well as actual acts, is reciprocal. The Categorical Imperative is present in the relations between people when through an attitude of respect certain actual acts follow and certain hypothetical acts would follow. In other words certain acts actual and hypothetical follow from what the Categorical Imperative logically requires, and the Categorical Imperative is present when certain acts actual and hypothetical follow.

Without due weight being given to the presence and importance of hypothetical acts as opposed to actual acts, the worry is that there may appear to be nothing displayed in the relations between people that shows the Categorical Imperative active in the relations, as the Categorical Imperative itself demands that it always should be.

It may be said that the interactions between people are too superficial and insubstantial, and the power relationship in the interaction too skewed one way, for the Categorical Imperative to be involved. ${ }^{8}$ It's not clear, it may be said, in what way we are treating someone as an end while we also treat him as a means. This thought is not of course the same as the crass error of saying that Kant was presenting the absurd demand that we never treat someone as a means. For, of course, the true demand of the Categorical Imperative is that we never treat someone merely as a means, but also always as an end (as ends-in-themselves) even while we treat him as a means. Indeed, it might be added that we should be extra sure to treat someone as an end especially when we treat someone as a means. We should be especially self-aware and alert to treating someone as an end when we treat him also as a means. Nevertheless, the claim is that in particular examples of interactions with others we have no straightforward concrete way of treating someone as an end, while we treat him (or use him) as a means. An additional obstacle, it is sometimes implied, may be the one-sided nature of the treatment or use; or one might say the relation of social position or power between two individuals.

The inability to see how the Categorical Imperative may, despite the lack of the appearance of acts actually displaying it, nevertheless be present in the relations between people, and may always be so, overlooks the existence of hypothetical acts that do just that. Not to see this is a significant mistake. For it fails to fully understand the way in which the principle of the Categorical Imperative rests upon a belief in the essential equal moral worth of individuals and their being the ultimate source and loci of all value. Even the claim that there is nothing actually happening in relations between people to show that Categorical Imperative is present, so that one is indeed treating them as an end while treating them as a means, often overlooks actual features of the relation that manifest the presence of the Categorical Imperative. Examples of this will be given shortly. However,

\footnotetext{
${ }^{8}$ A setting out of this thought might be as follows. 'The requirement never to treat another merely as a means is hard to satisfy in practice. Surely when I take a bus or order a meal I treat the driver or the waiter as a means: what it would be also to treat them as ends in themselves is unclear. Indeed, even apart from cases where the contracts between people are too slight or too distorted by the roles being played for Kant's requirement to be met straightforwardly, it is none too clear what it is to treat someone as an end in himself.' Tom Sorell, Moral Theory and Capital Punishment (Oxford: Blackwell/The Open University, 1987) 69.
} 
the central contention here is that even when actual acts seem to fail to manifest anything demanded by the Categorical Imperative, this overlooks a further fundamental way in which one may always treat others as ends - this is in terms of hypothetical acts.

The significance and presence of the Categorical Imperative, that it may and should be present in all our relations with others, are missed if the measure is only what is displayed in actual acts between people. As has been suggested, what is vital in responding to the categorical demand of the Categorical Imperative in treating someone as an end and not merely as a means, is not only actual acts, but also one's attitude towards the other person, and, moreover, one's prevailing attitude. It is in this way that hypothetical acts can enter the picture. The attitude is given substance and is made more than merely nominal through a consideration of the hypothetical acts that one would undertake should certain circumstances arise. Thus, hypothetical acts are born of, and exist embodied in, appropriate attitudes to others, and they are a vital constituent in treating the other as an end even when there is only a slight or no obvious indication that one is actually doing so. Indeed, having the right attitude that gives rise to certain hypothetical acts is essential to treating others as an end even while one may treat them as a means. It is not just what one does that matters, but also what one would do. What one would do, how one would treat others, exists latently and tacitly in one's attitude to others, and in the consequent disposition to behave in certain ways as circumstances arise. Morally appropriate hypothetical acts give substance to and are entailed by the attitude characterised by the Categorical Imperative that one should unconditionally always have towards others.

In fact, it is indispensable to understanding what the Categorical Imperative demands of us that we include what we would do in hypothetical situations. Only in that way may we show fully that our attitude to others embodies the appropriate kind of respect required by the Categorical Imperative. The hypothetical runs, or should run, silently in the background, as it were, in all our relations with others, and in so doing shows that our predispositions to act in certain ways born of our fundamental attitudes to them amounts to treating others with respect. In putting the Categorical Imperative principle into practice in our dealings with others we may do so, as will be seen, by carrying with us a generic attitude that covers an array of unspecified hypothetical acts in response to possible situations, and in so doing, there exists a sense in which we are treating, and may always treat, others as an end.

This paper does not purport to be an exercise in precise historical scholarly exegesis. ${ }^{9}$ Rather the paper is written in a Kantian spirit. There is nothing, however, about the principle of the Categorical Imperative that prevents it being viewed as including hypothetical acts as well as actual acts, since, after all, the principle concerns the treatment of others, and that in turn derives from our attitude to them, which includes what our consequent treatment would be in situations that might arise. Indeed, it would be surprising if this were not so. Nevertheless, this seems to have been over looked, and consequently the Categorical Imperative principle has a poorer reputation in the eyes of many as a powerful substantive contribution to ethical thinking than it otherwise would have. For it will often be said that there is nothing - or little, or nothing of sufficient significance - actually happening to indicate in our relations with others that the Categorical Imperative is in operation. The answer is that there does not need to be for it

\footnotetext{
${ }^{9}$ Brilliantly clear exegesis is to be found in Roger J. Sullivan, An Introduction to Kant's Ethics (Cambridge: Cambridge University Press, 1994).
} 
still to be the case that our relations with other are such that the Categorical Imperative is fully present.

The aim here is not to mount a general defence of the Categorical Imperative as an ethical principle - although I think such a defence may be given. Rather my aim is to refute the objection held against it that it all too often seems to fail to be displayed and is therefore absent in specific and mundane situations in such a way that it may be accused of being ethically insubstantial, when its central idea is that it should be the most significant moral demand of all and involved in all our relations with others.

\section{2.}

While not defending the Categorical Imperative respect for persons principle per se, it is necessary to try to give an account of what the principle means. An understanding of the principle involves taking it closer to the way we commonly think about ethics and the way we think ethically in concrete situations. In that sense, the meaning of the Categorical Imperative may be interpreted in a fairly straightforward way, one that chimes with our deepest ethical intuitions. Indeed, it is a central point of the principle that if we are not at least thinking along the lines of the principle, we may be said not to be thinking ethically at all. The idea of the principle, and the respect for persons demanded by it unconditionally in all our interactions with others, is that in our dealings with others we always take into account the will of the other and how that will would determine his life in such a way that we do not assume that our will may always override or trump the will of the other. ${ }^{10}$ This is tantamount to saying that we should not use others as mere things or even as if they were mere things. No moral obligations accrue directly to mere things. They may accrue indirectly because they are connected in some way to the will of others and are valued by them. But to treat someone as a mere means, and not also as an end, is to treat them as akin to a thing, or at best as a slave. This is implied by Kant when he says, 'Der Mensch aber ist keine Sache, mithin nicht etwas, das bloß als Mittel gebraucht werden kann, sondern muß bei allen seinen Handlungen jederzeit als Zweck an sich selbst betrachtet werden.' ${ }^{11}$ ['A human being, however, is not a thing and hence not something that can be used merely as a means, but must in all actions always be regarded as an end in itself.'] The word 'betrachtet' 12 ['regarded'] is significant here, and supports, I believe, the present argument for the importance of hypothetical acts and

\footnotetext{
${ }^{10}$ I make no strong claim about such a will being rational. Indeed, it may be said that 'rational will' is a tautology. This is not the place to defend this claim, but it may be argued that having the capacity to will at all must include rationality, in the sense that plans and the actions that follow may be judged normatively it may be said that they should or should not have happened, that they were correct or incorrect, as opposed to simply things that happen or do not happen as non-rational events. What is crucial here is that what follows is the will of the individual, in that it is his free choice. Whether that needs to be tied in separately to rationality is another matter. It might be noted however, in case this position is seen as moving too far away from the letter and even the spirit of Kant, that the Categorical Imperative ends up, it may be argued, in separating all entities in the world into persons and things: the rational entities (capable of willing) and the non-rational entities (incapable of willing). Only persons fall into the former class. It is the case of course that the Categorical Imperative applies to any being having humanity - that is to any person irrespective of whether its will is good or evil. See Allen W. Wood, Ibid, $120 f$.

${ }^{11}$ Foundation of Metaphysic of Morals, Chapter II, AA 4:429.20-23.

${ }^{12}$ Foundation of Metaphysic of Morals, Chapter II, AA 4:429.23
} 
in particular their foundation in a certain sort of prevailing attitude or stance towards persons.

We have life plans - things we want to do and want not to do - that derive from our desires, wants and needs, from what we value, and how our evaluations are ordered. That others are the same, and that we should not assume that our life plans may take no account of the life plans of others and ride roughshod over them in our relations with them, is what the principle of the Categorical Imperative asserts and absolutely requires of us. If you take no account of the life plans of others, you are not, in relation to others, even beginning to act morally towards them, you are not within the domain of morality at all - you are not with respect to those others acting as a moral agent nor treating them morally in accord with any moral maxims - and this is so even if good consequences for the other, as it were, in fact or accidentally follow from your actions. You might bring about something good, but the action or inaction involved without the principle being in play would not be a moral one. Any good consequences that follow would, even if intentional, carry no moral worth. The Categorical Imperative can only be in play for a subject, for a creature capable of an attitude of respect, for a person. What a river does might result in good or bad consequences, but they are all outside the moral sphere, and it makes no sense to judge the results morally as the river can take no heed of the Categorical Imperative principle. When a tree falls on your head, what happens is as it were beyond good and evil. The central point of significance argued for here is that acting morally necessarily removes the assumption that one's own will may, even when it can, in all circumstances trump that of another.

On the face of it, this may seem a modest requirement. However, a little reflection suggests that much of the greatest evil has occurred in the world when some have thought that their will could simply ignore and ride roughshod over the will of others. Sometimes this is even done and excused in pursuit of some supposed greater good. It is this that the Categorical Imperative necessarily prohibits by always requiring that no-one is ever treated as a mere means, even when a supposed good is an aim, let alone when it is not. Not to treat others as a mere means, but also as ends, is to treat them always as persons. ${ }^{13}$

\footnotetext{
${ }^{13}$ One is reminded of the heartfelt remark of an ex-prisoner-of-war held in a Japanese camp, who on release commented: 'I was a man again: I could say "no"'. In the camp he was not treated as a person, but as a virtual thing. What this meant was that his will counted for nothing in how others treated him. The Categorical Imperative principle was not in play.

Similarly, the Nazi Extermination Camp survivor Primo Levi showed how there was there was no 'why' in Auschwitz, only was. 'Driven by thirst, I eyed a fine icicle outside the window, within hand's reach. I opened the window and broke off the icicle, but at once a large, heavy guard prowling outside brutally snatched it away from me. "Warum?" I asked in my poor German. "Hier ist kein warum" [Here there is no why], he replied, pushing me inside with a shove.' Primo Levi, Survival in Auschwitz (New York: Simon \& Schuster, 1995), 28. The requirement and request for normative justification had ceased to exist in the way people were treated. They were just things for whom (or perhaps, 'for which') no normative justification for what happened to them was required nor could be demanded. Persons had become treated as things.

Emmanuel Levinas records that when he was a German POW (he had the good luck to be treated as a Frenchman rather than a Jew) he was, with several others, cutting down trees in the middle of the forest. Passers-by treated them as part of the landscape, and the only one to treat them as human was a big dog that greeted them when they came back to camp, for whom they were clearly men. When the guards eventually chased the dog off, he records that 'This dog was the last Kantian in Germany, without the brain needed to universalise maxims and drives.' Emmanuel Levinas, 'The Name of a Dog, or Natural Rights'.
} 
3.

If the Categorical Imperative principle is understood as explained above then it can be seen clearly, it will be argued, how the principle has an application in practice. The Categorical Imperative principle involves respecting the will of others in determining their own lives. That respect involves not thinking that one's own will in the treatment of others need take no account of the will of others. The key here is that taking account of the will of others includes not only actually acting towards them a certain way, but also, as embodied in one's attitude them, hypothetical acts that would occur should circumstances give rise to them. That there be such acts is morally required by the Categorical Imperative. Whatever they turn out to be, there should always be a range of hypothetical acts connected to certain circumstances that we should be prepared to undertake or at least give serious moral consideration to doing so. Taken together, one treats others as ends-in-themselves and not merely as means, by dealing with others with an appropriate attitude that may give rise to actual acts, but certainly would give rise to certain acts should the circumstances arise. These last remain hypothetical acts unless the circumstances do arise, but they are not thereby non-existent because they exist embodied in our attitude to others.

\section{4.}

There is now the opportunity to see how what is argued here might apply to a mundane example. Consider the case of taking a taxi, and one's relation with the taxi driver. It should be noted at the outset that applying the Categorical Imperative principle is always two-way between people, regardless of the balance of power and the means/ends relationship of people. This may seem obvious, but it is all too easily forgotten by one side or the other in the relations people have with each other, as it is the understanding of that relation presented here. One may be using the other more as a means than the other is

Difficult Freedom: Essays on Judaism, trans Seán Hand (Baltimore: The John Hopkins University Press, 1990).

Stephen Darwall writes, 'When someone uses your foot as his footrest, this is an injury, not just to your foot, but to your person. It is a failure to respect your dignity as someone who may not be so treated and who can insist on it. Adam Smith observes [Adam Smith, The Theory of Moral Sentiments (originally published, 1759), A. L. Macfie and D. D. Raphael, eds. (Indianapolis: LibertyClassics, 1982)] that we are apt to resent disrespect for our person as much as or more than physical or other psychic injury. "What enrages us against the man who injures or insults us," Smith writes "is the little account he seems to make of us" - "that absurd self-love [and we might add: self-conceit], by which he seems to imagine, that other people may be sacrificed at any time, to his conveniency."' Stephen Darwall, 'Respect and the SecondPerson Standpoint' Proceedings and Addresses of the American Philosophical Association, November 2004, Volume 78, Issue 2, 54.

And Peter Strawson says, 'We should consider also in much of our behaviour the benefit or injury resides mainly or entirely in the manifestation of the attitude itself.' P. F. Strawson, Freedom and Resentment, (London: Routledge, 2008), 76. 
using you; but regardless of that, the situation should never arise morally where one or other simply uses the other as a means and not also as an end. I hire a taxi to take me to the university. How are my dealings with the driver, my treatment of him, such that I am treating him as an end-in-himself even while I am treating him as a means? What is it about my attitude to him that makes this so?

The account defended here of how the Categorical Imperative principle may be understood holds that what is involved in its application is that I do not assume that another's actions necessarily be in accord with my will, so that therefore his will is disregarded and shown no respect. How can it be that I may not treat the taxi driver as I might the taxi-cab? First, how may my actions actually indicate this? Even this is often overlooked, even before we get onto hypothetical acts. The taxi driver will have things he wants to do, plans for his life both daily and overall, but which he has given up - taxi driving is a job after all, not a hobby - in order to do what I want to do. He is subsuming his will to my will for the purposes of the trip. There is a set of things that I can actually do that manifest an understanding on my part that this is what is occurring, and in so doing I treat him as an end and with respect even while I treat him as the means of getting to the university. I talk to him politely. I do not push him about like a thing, or even order him about like a slave, but ask him if he will take me to the university rather than tell him to do so. The other significant thing I do is pay him for his time. What this does is compensate him for taking him away from what he would will to do if he were not doing my will. The payment in fact has a double effect, as it may also facilitate his being able to do what he wills at another time - go fishing, have a few pints, take his family on holiday, and the like. These actual acts show that there is a clear and straightforward sense in which I am treating the driver not as a mere means, but also as an end, for I am treating him as a person whose will should be acknowledged and taken into account.

Some will say that these actual acts are too slight to constitute treating someone in accord with the Categorical Imperative. One may plausibly disagree with this, but fortunately there is no need to argue for it in any case, for there is something else going on here, or should be, that makes it the case that I am treating the driver as an end.

There is another essential way that I may be said to manifest the Categorical Imperative principle in my treatment of others, such that the principle is in play. It consists of an indeterminate set of hypothetical acts as embodied in my attitude towards the taxi driver. These arise from possible and more or less probable situations that may or may not occur, but if they were to occur they would lead to reactive acts on my part that indicate that I am treating him in accordance with the Categorical Imperative principle. They are encapsulated generically in my having the right pervasive attitude to the driver.

Suppose, having set off on our journey to the university, he receives an urgent radio message saying that he should go to the hospital where his mother is lying dying following an accident. My treating the driver in accordance with the Categorical Imperative principle always consists, whatever else it consists in, of an indeterminate array of possible situations whereby I would act so as to stop using him as a means and allow his will to determine what happens - to go to his mother, dropping me off at the road-side to take my chances hailing another taxi to the university - should certain situations arise. The way in which these hypothetical actions exist is that they are embodied in one's prevailing background attitude to another person. One may and can because of this treat another as an end while one treats them as a means even when little 
seems to be actually happening to indicate that one is. One may and can indeed treat another as an end while also treating him as a means when nothing seems to be happening to indicate that this is the case. One may and can determine to treat others as an end while one treats them as a means pervasively as a result of hypothetical acts embodied in one's attitudes to others. They may be unarticulated, or even unknown, since one cannot be aware of all of the situations that might arise. Yet this pervasive attitude perhaps held in place as a habit of thought - connected to hypothetical acts leaves one primed to act in morally appropriate ways should events turn out in any one of an array of particular ways. It is something one, as it were, may and should always carry around with one.

It may be objected that no details have been given of when one's will should give way to the will of another. What are the circumstances such that I would be using the driver as a mere means and not only as an end by demanding that he complete the journey despite his willing something else? When should I let his will cancel, or significantly modify, the way I am by my will using him as a means? For the purposes of the argument here such specifics are not required. All that is required is that there is a significant set of morally significant hypothetical circumstances in which my will as a duty bows out and his will asserts itself. The argument as to exactly what the circumstances are and what the moral response should be is a matter for detailed substantive ethics, but is not a special difficulty for hypothetical acts as compared to actual ones. After all, moral rules if there are any apply equally to both. If there are no moral rules, then this is not a special difficulty for hypothetical acts - it would be a difficulty, as far as their being considered moral or immoral is concerned, for all acts.

It's easy enough, however, to give specific examples, over which few would morally disagree, as in the case of the taxi driver's dying mother. It would be clear to most, except in the most bizarre circumstances, that the requirement that the driver visit his dying mother before she dies outweighs the importance of the lecture I might miss if I am late at the university. One may indeed work this out by the application of certain principles and present a justification, such cases simply being the meat and drink of substantial ethical thinking. ${ }^{14}$ It is not, however, hard to think of cases either side of the line of giving way or not giving way to another. On one side it is morally obvious that one should give way to another, on the other side it would be morally absurd to expect one to give way to another. That some examples are more difficult and lie on the line does not mean there is not a line, that most of us may agree on morally, with some cases clearly on one side or the other.

\footnotetext{
${ }^{14}$ The proportion of actual acts to hypothetical acts and their characteristics required by the Categorical Imperative will vary according the to the depth and intimacy of the relationship with others. If I buy something in a shop say, very little in the way of actual treatment of the shop assistant is required by the Categorical Imperative apart from normal politeness, while a considerable amount of hypothetical acts remain - should the shop assistant be attacked I might defend her; should she have to leave on a genuine emergency, I may let her go without undue protest, and in neither case would I irately demand she complete my order. If however one is dealing with the relation between family members or between friends, the balance as well as the content of actual and hypothetical acts will be different and be partly dependent on the expectations that are part and parcel of those relationships for whatever reason - in this case far more in the way of actual acts, as well as perhaps further hypothetical acts and of a different sort, may rightly be morally expected. On this see Diane Jeske, Rationality and Moral Theory: How Intimacy Generates Reasons (London: Routledge, 2008).
} 
There is in any case no special difficulty with specifying what acts should morally speaking be undertaken and which not, involved in the claim that the Categorical Imperative principle is play. The Categorical Imperative is in play because of respect being embodied in a certain attitude, and that attitude points to a set of hypothetical acts that would display the respect demanded by the Categorical Imperative. The Categorical Imperative points to certain hypothetical acts, as well as actual ones, and those acts show that the Categorical Imperative is present in my relation to others, and may always be so as is categorically required.

The Categorical Imperative principle defines when ethical consideration should be evoked and apply. It is sufficient for this principle to be in play that my attitude is such that I have in mind that there may be situations in my dealings with another where I say to myself that I may not demand of him that he act in accord with my will rather than his own. In order to know exactly what to do I have to appeal to substantive ethics. It is the vast array of hypothetical acts that is overlooked by those who think that the principle of respect for persons as set out in the Categorical Imperative has little application in practice. In our dealings with others we show that we respect them in accordance with the principle by having these hypothetical acts running, usually silently and tacitly, in the background in all our dealing with others. It is in this way, through our willingness to do morally appropriate hypothetical acts, along with the ways we actually act morally, that we may always treat others always as ends, even granted that what we actually appear to be doing is relatively slight. These hypothetical acts should inform all our relations with others if we want even to begin to act so that we treat others in accordance with the Categorical Imperative, that is, as persons and so morally.

The Open University j.a.shand@open.ac.uk http://open.academia.edu/JohnShand

John Shand is an Associate Lecturer in Philosophy at The Open University. He has edited several books, and is author of Philosophy and Philosophers: An Introduction to Western Philosophy (Routledge, 2002) and Arguing Well (Routledge, 2000) and of numerous articles, including 'Limits, Perspectives, and Thought' Philosophy, 84, No. 329, July 2009. 